\title{
GAMBARAN ASUPAN PURIN PADA REMAJA DI KABUPATEN MINAHASA
}

\author{
${ }^{1}$ Ningsi Hadji Ali \\ ${ }^{2}$ Billy J. Kepel \\ ${ }^{2}$ Widdhi Bodhi \\ ${ }^{1}$ Kandidat Skripsi Fakultas Kedokteran Universitas Sam Ratulangi Manado \\ ${ }^{2}$ Bagian Kimia Fakultas Kedokteran Universitas Sam Ratulangi Manado \\ Email: ningsihadjiali@yahoo.com
}

\begin{abstract}
High purine intake can result in hyperuricemia which leads to gouthy arthritis and formation of kidney stone. High purine concentration is mainly contained in animal protein. Minahasa ethnic people have a habit of holding events where there is feast party and the majority of Minahasa signature dishes are animal product. This study aims to describe the purine intake in adolescents in Minahasa Regency. This research design is a descriptive crosssectional study with 40 study subjects. Sample is students of SMKN 2 and SMKN 3 Tondano in Minahasa Regency. Purine intake is measured by using Food Frequency Questionnaire (FFQ). The average of purine intake among adolescents in Minahasa Regency is 91,89 to $1028,44 \mathrm{mg} /$ day, $40 \%$ adolescents consume purine rich foods, that consist of $35 \%$ boys and $5 \%$ girls. There are 52,5\% adolescents consume foods with moderate purine content in high frequency and $40 \%$ adolescents consume foods with high purine content in high frequency. The conclusion of this study is the average of purine intake among adolescents in Minahasa Regency is quite high. It requires dietary knowledge of purine containing foods in order to reduce purine intake to prevent the increasing of hyperuricemia incidence and its impacts.
\end{abstract}

Keywords: purine intake, adolescent, Minahasa Regency

\begin{abstract}
Abstrak: Asupan purin yang tinggi dapat menyebabkan terjadinya hiperurisemia yang dapat berakhir dengan gout arthritis dan batu ginjal. Kadar purin yang tinggi terutama terkandung dalam protein hewani. Masyarakat etnis Minahasa memiliki kebiasaan menggelar acara syukuran yang diikuti dengan pesta makan dan makan makanan khas Minahasa yang sebagian besar berasal dari hewani. Penelitian ini bertujuan untuk mengetahui gambaran asupan purin pada remaja di Kabupaten Minahasa. Penelitian ini menggunakan desain deskriptif crosssectional dengan jumlah subjek 40 orang. Subjek dari penelitian ini yaitu siswa-siswi SMK Negeri 2 Tondano dan SMK Negeri 3 Tondano di Kabupaten Minahasa. Data asupan purin diukur dengan Food Frequency Questionnaire (FFQ). Rata-rata asupan purin remaja di Kabupaten Minahasa sebesar 91,89-1028,44 mg/hari, dengan 40\% remaja mengkonsumsi purin dalam jumlah yang tinggi, yang terdiri dari 35\% remaja pria dan 5\% remaja wanita. Remaja yang mengkonsumsi makanan yang mengandung purin sedang dengan frekuensi tinggi sebanyak 52,5\% dan remaja yang mengkonsumsi makanan yang mengandung purin tinggi dengan frekuensi tinggi sebanyak $40 \%$. Kesimpulan penelitian ini yaitu rata-rata asupan purin remaja di Kabupaten Minahasa cukup tinggi. Hal ini membutuhkan peningkatan pengetahuan tentang kandungan purin dalam makanan sehingga dapat membatasi jumlah asupan purin untuk mencegah meningkatnya kejadian hiperurisemia dan penyakit yang ditimbulkannya.
\end{abstract}

Kata kunci: asupan purin, remaja, Kabupaten Minahasa 
Pola makan masyarakat yang tidak sehat dengan mengkonsumsi makanan berprotein tinggi, terutama protein hewani yang mengandung kadar purin tinggi menyebabkan kejadian hiperurisemia semakin meningkat. ${ }^{1}$ Mengkonsumsi makanan tinggi purin akan meningkatkan kadar asam urat dalam darah, yang merupakan predisposisi terjadinya gout arthritis dan batu ginjal. ${ }^{2}$ Kandungan purin yang tinggi terutama terdapat dalam jeroan, kerang, kepiting, dan ikan teri. ${ }^{3}$ Asupan purin merupakan faktor risiko paling kuat yang berhubungan dengan kejadian hiperurisemia. ${ }^{4}$

Hasil survey WHO-ILAR COPCORD (World Health Organization-International League of Associations for Rheumatology Community Oriented Program for Control of Rheumatic Disease) di pedesaan Sulawesi Utara dan Manado menemukan adanya hubungan antara asam urat menahun dengan pola konsumsi dan gaya hidup, di antaranya konsumsi minuman keras dan kebiasaan makan makanan kaya purin. ${ }^{5}$ Suku bangsa dengan prevalensi penyakit asam urat tertinggi di dunia pada orang Maori di Australia, sedangkan di Indonesia prevalensi tertinggi pada penduduk pantai dan yang paling tinggi di daerah Manado-Minahasa, karena kebiasaan makan ikan dan mengkonsumsi alkohol. ${ }^{3}$ Angka kejadian hiperurisemia di Minahasa pada tahun 1999 sebesar 34,30\% pada pria dan $23,31 \%$ pada wanita usia dewasa muda. ${ }^{6}$ Prevalensi hiperurisemia pada remaja obes di Kota Tomohon pada tahun 2011 sebesar 25\%.

Masa remaja merupakan masa peralihan dari masa kanak-kanak menuju masa dewasa, dimana terjadi perubahan dari aspek biologis, kognitif, dan sosioemosional. ${ }^{8}$ Masa remaja berlangsung pada usia 13 sampai 18 tahun. ${ }^{9}$ Masa remaja merupakan salah satu periode tumbuh kembang yang penting dan menentukan pada periode perkembangan berikutnya. $^{10}$ Masa remaja merupakan periode perkembangan yang kritis dimana ia mulai membuat keputusan independen untuk memilih makanannya sendiri. ${ }^{11}$
Suatu hasil penelitian menunjukkan bahwa orang Minahasa memiliki budaya senang makan. ${ }^{7}$ Jumlah penduduk etnis Minahasa merupakan yang terbanyak di antara etnis yang ada di Propinsi Sulawesi Utara. $^{12}$ Etnis Tondano (Toulour) merupakan salah satu sub-etnis dari etnis Minahasa. ${ }^{13}$ Masyarakat etnis Minahasa mempunyai kebiasaan party yang diikuti dengan pesta makan atau makan makanan khas Minahasa yang sebagian besar berasal dari lemak hewani. Kebiasaan pesta atau acara syukuran dalam rangka Hari Pengucapan Syukur, hari ulang tahun, syukuran tiga hari meninggalnya seorang anggota keluarga, Mingguan atau memperingati tujuh hari meninggal, 40 hari meninggal, satu tahun meninggal, dan lain sebagainya membuat setiap orang etnis Minahasa mempunyai kemungkinan untuk terpapar dengan makanan etnis Minahasa yang sering dihidangkan pada saat acara pesta atau acara ucapan syukur tersebut. ${ }^{12}$

Berdasarkan berbagai uraian di atas, penulis terdorong dan merasa perlu untuk melakukan penelitian mengenai gambaran asupan purin pada remaja di Kabupaten Minahasa.

\section{METODE PENELITIAN}

Penelitian ini menggunakan desain deskriptif cross-sectional. Penelitian ini dilaksanakan di SMK Negeri 2 Tondano dan di SMK Negeri 3 Tondano. Penelitian dilakukan pada bulan Agustus 2012 sampai bulan Januari 2013. Pengambilan data dilakukan pada bulan November 2012 sampai bulan Januari 2013. Populasi dalam penelitian ini ialah seluruh siswa-siswi SMA dan SMK yang ada di Kabupaten Minahasa. Sampel penelitian ini ialah siswa-siswi SMK Negeri 2 Tondano dan SMK Negeri 3 Tondano yang berusia 13 sampai 18 tahun yang berjumlah 40 orang, yang dihitung berdasarkan rumus proporsi tunggal (single proportion). Metode pengambilan sampel yang digunakan dalam penelitian ini yaitu metode simple random sampling. Variabel dalam penelitian ialah asupan purin. Asupan purin adalah 
konsumsi makanan yang mengandung purin tinggi, sedang, dan rendah yang diukur dengan Food Frequency Questionnaire (FFQ). Remaja adalah siswa-siswi yang berusia 13-18 tahun yang bersekolah di SMK Negeri 2 Tondano dan SMK Negeri 3 Tondano. Instrumen yang digunakan dalam penelitian ini ialah Food Frequency Questionnaire (FFQ), Food Model dan foto jenis makanan yang mengandung purin. Data pada penelitian ini ialah data primer yang merupakan data langsung melalui wawancara pengisian Food Frequency Questionnaire (FFQ) yang dilakukan kepada responden. Pengumpulan data diawali dengan pengurusan izin penelitian kemudian ditentukan sekolah yang dipilih secara acak dari seluruh SMA dan SMK di Kabupaten Minahasa, yaitu SMK Negeri 2 Tondano dan SMK Negeri 3 Tondano. Pengambilan sampel dilakukan secara acak dengan metode simple random sampling dari 1677 siswa-siswi di SMK Negeri 2 Tondano dan SMK Negeri 3 Tondano yang masuk dalam sampling frame untuk memilih 40 siswa-siswi dari sekolah tersebut. Peneliti menjelaskan tujuan dan manfaat penelitian, kemudian melakukan informed consent dengan orang tua responden. Melakukan wawancara pada responden untuk pengisian Food Frequency Questionnaire yang dilakukan dengan menunjukkan Food Model dan foto jenis makanan yang mengandung purin kepada responden untuk memudahkan dalam mengingat jenis makanan yang dimaksud oleh peneliti. Peneliti melatih satu orang pewawancara untuk menyamakan persepsi dalam melakukan wawancara terhadap responden. Data dikumpulkan dan dihitung kemudian disajikan dalam bentuk tabel berdasarkan variabel penelitian dan dianalisa sesuai dengan presentasinya.

\section{HASIL PENELITIAN}

Berdasarkan jenis kelamin, Tabel 1 . menunjukkan bahwa dari 40 responden, 21 orang $(52,5 \%)$ merupakan responden pria dan 19 orang $(47,5 \%)$ merupakan responden wanita.
Tabel 2 menunjukkan bahwa dari 40 responden, tidak terdapat responden berumur 13 tahun, terdapat 6 (15\%) responden berumur 14 tahun, 14 (35\%) responden berumur 15 tahun, 10 (25\%) responden berumur 16 tahun, 17 (15\%) responden berumur 17 tahun, dan 18 (10\%) responden berumur 18 tahun.

Tabel 3 menunjukkan bahwa jumlah rata-rata asupan purin responden dalam sehari sebesar 91,89-1028,44 mg/hari, dengan $\leq 78,02 \mathrm{mg} /$ hari rata-rata asupan purin dari makanan dengan kandungan purin rendah, 28,33-314,79 mg/hari ratarata asupan purin dari makanan dengan kandungan purin sedang, dan 63,56-635,63 $\mathrm{mg} /$ hari rata-rata asupan purin dari makanan dengan kandungan purin tinggi.

Tabel 4 menunjukkan bahwa jumlah responden yang mengkonsumsi purin $<600$ mg/hari sebanyak 14 (35\%) orang, responden yang mengkonsumsi purin dalam batas normal sebanyak 10 (25\%) orang, dan responden yang mengkonsumsi purin $>1000 \mathrm{mg} /$ hari sebanyak 16 (40\%) orang.

Tabel 5 menunjukkan jumlah responden pria yang mengkonsumsi purin rendah sebanyak 2 (5,0\%) orang, responden pria yang mengkonsumsi purin dalam batas normal sebanyak 5 (12,5\%) orang, responden pria yang mengkonsumsi purin tinggi sebanyak 14 (35,0\%) orang, sedangkan responden wanita yang mengkonsumsi purin rendah sebanyak 12 (30,0\%) orang, responden wanita yang mengkonsumsi purin dalam batas normal sebanyak 5 (12,5\%) orang, dan responden wanita yang mengkonsumsi purin tinggi sebanyak 2 (5,0\%) orang.

Tabel 6 menunjukkan bahwa berdasarkan umur, responden yang paling banyak mengkonsumsi purin adalah responden yang berumur 15 tahun, yaitu sebanyak 3 (7,5\%) responden yang mengkonsumsi purin rendah, $4(10,0 \%)$ responden yang mengkonsumsi purin dalam batas normal, dan 8 (20,0\%) responden yang mengkonsumsi purin tinggi.

Tabel 7 menunjukkan jumlah responden yang mengkonsumsi makanan yang mengandung purin rendah dengan 
frekuensi tinggi ( $\geq 1 \mathrm{x} /$ minggu) sebanyak 20 (50\%) orang dan jumlah responden mengkonsumsi makanan rendah purin dengan frekuensi rendah sebanyak 20 (50\%) orang.

Tabel 8 menunjukkan jumlah responden yang mengkonsumsi makanan yang mengandung purin sedang dengan frekuensi tinggi sebanyak 21 (52,5\%) orang dan jumlah responden yang mengkonsumsi makanan yang mengandung purin sedang dengan frekuensi rendah sebanyak 19 (47,5\%) orang.

Tabel 9 menunjukkan jumlah responden yang mengkonsumsi makanan yang mengandung purin tinggi dengan frekuensi tinggi sebanyak 16 (40\%) orang dan jumlah responden yang mengkonsumsi makanan yang mengandung purin tinggi dengan frekuensi rendah sebanyak 24 (60\%) orang.

Tabel 1. Distribusi responden menurut jenis kelamin

\begin{tabular}{lcc}
\hline Jenis Kelamin & n & \% \\
\hline Pria & 21 & 52,5 \\
Wanita & 19 & 47,5 \\
Jumlah & 40 & 100,0 \\
\hline
\end{tabular}

Tabel 2. Distribusi responden menurut umur

\begin{tabular}{lrr}
\hline Umur & $\mathrm{n}$ & $\%$ \\
\hline 13 Tahun & - & - \\
14 Tahun & 6 & 15 \\
15 Tahun & 14 & 35 \\
16 Tahun & 10 & 25 \\
17 Tahun & 17 & 15 \\
18 Tahun & 18 & 10 \\
Jumlah & 40 & 100 \\
\hline
\end{tabular}

Tabel 3. Distribusi rata-rata asupan purin per hari menurut kandungan purin dalam makanan

\begin{tabular}{lc}
\hline Kandungan Purin & $\begin{array}{c}\text { Asupan Purin } \\
\text { (mg/hari) }\end{array}$ \\
\hline Rendah & $\leq 78,02$ \\
Sedang & $28,33-314,79$ \\
Tinggi & $63,56-635,63$ \\
Jumlah & $91,89-1028,44$ \\
\hline
\end{tabular}

Tabel 4. Distribusi responden berdasarkan asupan purin per hari

\begin{tabular}{lcc}
\hline Asupan Purin & n & \% \\
\hline$<600 \mathrm{mg} /$ hari & 14 & 35 \\
$600-1000 \mathrm{mg} / \mathrm{h} a r i$ & 10 & 25 \\
$>1000 \mathrm{mg} /$ hari & 16 & 40 \\
\hline Jumlah & 40 & 100 \\
\hline
\end{tabular}

Tabel 5. Distribusi responden berdasarkan asupan purin per hari menurut jenis kelamin

\begin{tabular}{|c|c|c|c|c|}
\hline \multirow{2}{*}{$\begin{array}{c}\text { Jenis } \\
\text { Kelamin }\end{array}$} & $\begin{array}{c}\text { Asupan Purin } \\
<600 \mathrm{mg} / \text { hari }\end{array}$ & $\begin{array}{c}\text { Asupan Purin } \\
600-1000 \mathrm{mg} / \text { hari }\end{array}$ & $\begin{array}{l}\text { Asupan Purin } \\
>1000 \mathrm{mg} / \text { hari }\end{array}$ & \multirow[t]{2}{*}{ Jumlah } \\
\hline & $\mathrm{n}(\%)$ & $\mathrm{n}(\%)$ & $\mathrm{n}(\%)$ & \\
\hline Pria & 2 (5,0\%) & 5 (12,5\%) & $14(35,0 \%)$ & 21 (52,5\%) \\
\hline Wanita & $12(30,0 \%)$ & 5 (12,5\%) & 2 (5,0\%) & 19 (47,5\%) \\
\hline Jumlah & $14(35,0 \%)$ & $10(25,0 \%)$ & $16(40,0 \%)$ & $40(100,0 \%)$ \\
\hline
\end{tabular}

Tabel 6. Distribusi reponden berdasarkan asupan purin per hari menurut umur

\begin{tabular}{ccccc}
\hline \multirow{2}{*}{ Umur } & $\begin{array}{c}\text { Asupan Purin } \\
<\mathbf{6 0 0} \mathbf{m g} / \mathbf{h a r i}\end{array}$ & $\begin{array}{c}\text { Asupan Purin 600- } \\
\mathbf{1 0 0 0 m g / h a r i}\end{array}$ & $\begin{array}{c}\text { Asupan Purin } \\
>\mathbf{1 0 0 0 m g / h a r i}\end{array}$ & Jumlah \\
\cline { 2 - 4 } & $\mathrm{n}(\%)$ & $\mathrm{n}(\%)$ & $\mathrm{n}(\%)$ & \\
\hline 14 Tahun & $2(5,0 \%)$ & $2(5,0 \%)$ & $2(5,0 \%)$ & $6(15,0 \%)$ \\
15 Tahun & $3(7,5 \%)$ & $4(10,0 \%)$ & $8(20,0 \%)$ & $14(37,5 \%)$ \\
16 Tahun & $2(5,0 \%)$ & $4(10,0 \%)$ & $3(7,5 \%)$ & $9(22,5 \%)$ \\
17 Tahun & $4(10,0 \%)$ & - & $2(5,0 \%)$ & $6(15,0 \%)$ \\
18 Tahun & $3(7,5 \%)$ & - & $1(2,5 \%)$ & $4(10,0 \%)$ \\
Jumlah & $14(35,0 \%)$ & $10(25,0 \%)$ & $16(40,0 \%)$ & $40(100,0 \%)$ \\
\hline
\end{tabular}


Tabel 7. Distribusi responden berdasarkan frekuensi asupan makanan yang mengandung purin rendah

\begin{tabular}{llc}
\hline Frekuensi Asupan & n & \% \\
\hline Tinggi $(\geq 1 \mathrm{x} /$ minggu $)$ & 20 & 50 \\
Rendah $(<1 \mathrm{x} /$ minggu $)$ & 20 & 50 \\
$\quad$ Jumlah & 40 & 100 \\
\hline
\end{tabular}

Tabel 8. Distribusi responden berdasarkan frekuensi asupan makanan yang mengandung purin sedang

\begin{tabular}{lcc}
\hline Frekuensi Asupan & n & $\mathbf{\%}$ \\
\hline Tinggi $(\geq 1 \mathrm{x} /$ minggu $)$ & 21 & 52,5 \\
Rendah $(<1 \mathrm{x} /$ minggu $)$ & 19 & 47,5 \\
$\quad$ Jumlah & 40 & 100,0 \\
\hline
\end{tabular}

Tabel 9. Distribusi responden berdasarkan frekuensi asupan makanan yang mengandung purin tinggi

\begin{tabular}{lcc}
\hline Frekuensi Asupan & n & \% \\
\hline Tinggi $(\geq 1 \mathrm{x} /$ minggu $)$ & 16 & 40 \\
Rendah $(<1 \mathrm{x} /$ minggu $)$ & 24 & 60 \\
\hline Jumlah & 40 & 100 \\
\hline
\end{tabular}

\section{PEMBAHASAN}

Penelitian ini dilaksanakan di SMK Negeri 2 Tondano dan SMK Negeri 3 Tondano yang berada di Kabupaten Minahasa. Rata-rata asupan purin dalam sehari dari 40 responden yang menjadi subjek penelitian yaitu sebesar 91,891028,44 mg/hari, dengan rata-rata asupan purin yang berasal dari makanan dengan kandungan purin tinggi sebesar 63,56$635,63 \mathrm{mg} /$ hari, rata-rata asupan purin dari makanan dengan kandungan purin sedang sebesar 28,33-314,79 mg/hari, dan rata-rata asupan purin dari makanan dengan kandungan purin rendah sebesar $\leq 78,02$ $\mathrm{mg} /$ hari. Hasil penelitian sebelumnya yang dilaksanakan pada penduduk Kota Denpasar pada tahun 2005 didapatkan konsumsi purin rata-rata sebesar 72,89511,9 mg/hari. ${ }^{48}$ Jika dibandingkan dengan penelitian tersebut, maka asupan purin yang dikonsumsi oleh remaja di Kabupaten Minahasa memiliki angka yang relatif lebih tinggi. Hal ini dihubungkan dengan budaya makan masyarakat Minahasa yang gemar menggelar pesta atau makan makanan khas Minahasa yang sebagian besar berasal dari hewani. ${ }^{12}$ Masyarakat di Sulawesi Utara khususnya masyarakat Minahasa memiliki kecenderungan menggelar acara-acara atau pesta, seperti pesta ulang tahun pribadi, pesta ulang tahun perkawinan, syukuran karena naik pangkat, jabatan baru, lulus ujian, mendapat pekerjaan, dan ucapan syukur lainnya yang menyediakan sejumlah makanan untuk para tamu yang hadir. Jumlah makanan dalam satu pesta biasanya bervariasi, mulai dari makanan pembuka, makanan pokok sampai dengan makanan penutup. $^{44}$

Berdasarkan jumlah responden yang mengkonsumsi makanan yang mengandung purin, didapatkan 35\% responden mengkonsumsi <600 mg purin/hari, 25\% responden mengkonsumsi 600-1000 mg purin/hari, dan $40 \%$ responden mengkonsumsi >1000 mg purin/per hari. Diet normal mengandung 600-1000 mg purin per hari. ${ }^{33}$ Tubuh menyediakan $85 \%$ senyawa purin untuk kebutuhan setiap hari, sehingga kebutuhan purin dari makanan hanya sekitar $15 \%{ }^{27}$ Mengkonsumsi makanan tinggi purin merupakan faktor risiko dari peningkatan kadar asam urat dalam darah (hiperurisemia). ${ }^{48}$ Hasil penelitian pada remaja di Kabupaten Minahasa ini menunjukkan bahwa $40 \%$ responden memiliki risiko terjadinya hiperurisemia yang lebih besar. Keadaan hiperurisemia akan menyebabkan terjadinya artritis gout dan nefropati gout. ${ }^{25}$ Asupan purin harus dibatasi sekitar 100$150 \mathrm{mg}$ purin dalam sehari bagi penderita artritis gout. $^{33}$

Berdasarkan rata-rata asupan purin per hari didapatkan 35\% responden dengan jenis kelamin pria mengkonsumsi $>1000$ mg purin per hari dan 5\% responden dengan jenis kelamin wanita mengkonsumsi $>1000 \mathrm{mg}$ purin per hari. Hal ini menujukkan bahwa lebih banyak remaja dengan jenis kelamin pria yang mengkonsumsi purin tinggi dibandingkan dengan remaja dengan jenis kelamin wanita. 
Berdasarkan umur di antara 13-18 tahun, didapatkan responden yang paling banyak mengkonsumsi purin yaitu responden yang berumur 15 tahun dengan jumlah $7,5 \%$ responden mengkonsumsi $<600 \mathrm{mg}$ purin/hari, $10 \%$ responden mengkonsumsi 600-1000 mg purin/hari, dan $20 \%$ responden mengkonsumsi $>1000$ mg purin/hari.

Berdasarkan frekuensi asupan, didapatkan 50\% responden mengkonsumsi makanan yang mengandung purin rendah dengan frekuensi tinggi (satu kali atau lebih dari satu kali dalam seminggu), 52,5\% responden mengkonsumsi makanan yang mengandung purin sedang dengan frekuensi tinggi, dan $40 \%$ responden mengkonsumsi makanan yang mengandung purin tinggi dengan frekuensi tinggi. Penelitian sebelumnya menunjukkan bahwa 38,5\% masyarakat Minahasa mempunyai kebiasaan makan makanan khas Minahasa dengan frekuensi dua kali atau lebih dari dua kali dalam seminggu. Makanan khas Minahasa sebagian besar berasal dari produk hewani. ${ }^{45}$ Makanan yang bersumber dari produk hewani mengandung purin yang tinggi. ${ }^{27}$ Suatu tulisan menyebutkan bahwa terlalu banyak mengkonsumsi makanan dengan kandungan purin sedang lebih memungkinkan terjadinya peningkatan kadar asam urat dalam darah dibandingkan dengan sedikit mengkonsumsi makanan dengan kandungan purin tinggi. ${ }^{49}$ Makanan dengan kandungan purin rendah dapat dikonsumsi setiap hari. ${ }^{29}$

\section{SIMPULAN}

Berdasarkan hasil penelitian yang ditemukan, maka dapat disimpulkan bahwa rata-rata asupan purin remaja di Kabupaten Minahasa cukup tinggi yaitu sebesar 91,891028,44 mg/hari, dengan $40 \%$ remaja mengkonsumsi purin dalam jumlah yang tinggi, yaitu 35\% dari remaja pria dan 5\% dari remaja wanita. Remaja yang mengkonsumsi makanan yang mengandung purin sedang dengan frekuensi tinggi sebanyak 52,5\% dan remaja yang mengkonsumsi makanan yang mengandung purin tinggi dengan frekuensi tinggi sebanyak $40 \%$.

\section{UCAPAN TERIMA KASIH}

Ucapan terima kasih disampaikan pada Dr. Aaltje E. Manampiring, MKes, DR. Dra. Fatimawali, MSi, Apt, Daniel Robert, SST, MKes, Hendra Herlambang, SKM, dan pada semua pihak yang baik secara langsung maupun tidak langsung telah menumbuhkan ide atau gagasan dalam pemikiran penulis sehingga dapat menyelesaikan artikel ini.

\section{DAFTAR PUSTAKA}

1. Pribadi FW, Ernawati DA. Efek catechin terhadap kadar asam urat, c-reaktive protein (crp) dan malondialdehid darah tikus putih (rattus norvegicus) hiperurisemia. Mandala of Health. 2010;4:39.

2. Damayanti D. Panduan Lengkap Mencegah dan Mengobati Asam Urat. Yogyakarta: Araska, 2012; p.43.

3. Kartikawati. Awas Bahaya Kolesterol dan Asam Urat bagi Kita. Jawa Tengah: Vivo Publisher, 2011; p.81-2.

4. Setyoningsih R. Faktor-faktor yang berhubungan dengan kejadian hiperurisemia pada pasien rawat jalan rsup dr. kariadi semarang [skripsi]. Semarang: Fakultas Kedokteran Universitas Diponegoro; 2009.

5. Muniroh L, Martini S, Nindya TS, Solfaine R. Minyak atsiri kunyit sebagai anti radang pada penderita gout artritis dengan diet tinggi purin. Makara Kesehatan. 2010;14:58.

6. Rotty LWA. Gambaran asam urat pada suku minahasa usia dewasa muda [Tesis]. Manado: Fakultas Kedokteran Universitas Sam Ratulangi; 1999.

7. Manampiring A, Bodhi W. Prevalensi hiperurisemia pada remaja obese di kota tomohon. Laporan Penelitian Itek dan SeniLembaga Penelitian Universitas Sam Ratulangi Manado. 2011.

8. Santrock JW. Adolescence (Edisi ke-12). New York: McGraw-Hill, 2008; p.16-7.

9. Maria U. Peran persepsi keharmonisan keluarga dan konsep diri terhadap kecenderungan kenakalan remaja [Tesis]. 
Jogjakarta: Program Studi Psikologi Sekolah Pascasarjana Universitas Gadjah Mada; 2007.

10. Sargowo D, Andarini S. The relationship between food intake and adolescent metabolic syndrome. J Kardiol Indones. 2011;32:17.

11. Budiman A, Lie $M$, Siswanto $R$, Fernando, Wijaya C, Yana $C$, et al. Tontonan televisi mempengaruhi pola makan remaja? Dokter Sehat. 2009 Feb 9 [cited 2012 Nov 1]. Available from: http://doktersehat.com/tontonan-televisimempengaruhi-pola-makan-remaja/.

12. Kandou GD. Kebiasaan makan makanan etnik minahasa di provinsi sulawesi utara. Jurnal Kesehatan Masyarakat. 2009;3:53,55.

13. Rogi OHA, Siswanto W. Identifikasi aspek simbol dan norma cultural pada arsitektur rumah tradisional di minahasa. EKOTON. 2009;9:47.

14. Hidayat R. Gout dan hiperurisemia. Medicinus. 2009;22:47.

15. Dewanti S. Buku Pintar Kesehatan Kolesterol, Diabetes Mellitus, dan Asam Urat. Jawa Tengah: Kawan Kita, 2010; p.112-14,128-29,136-37.
16. Almatsier S. Penuntun Diet Edisi Baru. Instalasi Gizi Perjan RS Dr. Cipto Mangunkusumo dan Asosiasi Dietisien Indonesia. Jakarta: PT Gramedia Pustaka Utama, 2008; p.200.

17. Mulyatno KC. Diet tepat untuk penderita asam urat [homepage on the Internet]. Nodate [cited 2013 Jan 19]. Available from:

http://itd.unair.ac.id/index.php?option=com _content\&view=article\&id=102:diet-tepatuntuk-penderita-asamurat\&catid=40: health-news\&Itemid=113.

18. Sumual EJ. Pengembangan entrepreneur melaui usaha jasa boga mahasiswa jurusan pkk. Seminar Internasional. APTEKINDO. 2012.

19. Kandou GD. Kebiasaan makan makanan etnik minahasa di provinsi sulawesi utara. Jurnal Kesehatan Masyarakat. 2009;3:54-5.

20. Hensen, Putra TR. Hubungan konsumsi purin dengan hiperurisemia pada suku bali di daerah pariwisata pedesaan. J Peny Dalam. 2007;8:40.

21. Soeroso J, Algristian $\mathbf{H}$. Asam Urat. Jakarta: Penebar Swadaya Grup, 2012; p.96. 